The Association of Clinical Pathologists : 87 th general meeting

The 87 th general meeting of the Association of Clinical Pathologists was held at Imperial College, London on 23 and 24 September 1971. The meeting, as well as offering the opportunity for individual scientific communications, abstracts of which follow, included four symposia: 1 'Design of laboratories'; 2 'The WHO programme for the histological definition and classification of tumours'; 3 'Effects of centralization on laboratory services'; and 4 'Micrococci: the classification, ecology, and pathogenicity of coagulasenegative staphylococci'. The Presidential Address by A. G. Marshall was on 'The body politic in pathology'.

\section{A Laboratory Study of Macrocytic Anaemia in the North-east Region of Scotland, 1965-70}

R. J. L. DAVIDSON (City Hospital Aberdeen)

This survey is based on 812 laboratory proven cases of macrocytic anaemia (excluding macrocytic anaemia of pregnancy) detected on routine screening of blood samples submitted by the general practitioners of the N.E. Region during 1965-70 inclusive. Some of the epidemiological and laboratory findings, including the serum $B_{12}$ and folate status, are presented and briefly discussed.

Of the 1,158 cases initially suspected of having a macrocytic anaemia on morphological grounds, $991 \quad(85.6 \%)$ were followed up by the laboratory and of these $812(81.9 \%)$ were found to have low serum $B_{12}$ and/or low serum folate levels. Only $257(25.9 \%)$ of the patients followed up were admitted to hospital for further investigation. The potential value of a diagnostic and advisory service in haematology for general practitioners is emphasized.

\section{Association of White Cell and Red Cell Antibodies in Human Sera}

D. C. O. JAMES, J. ROSS, and LEE HUMMELEN, (Westminster Hospital, London)

Five hundred and eighteen serum specimens containing known red cell antibodies were tested for the presence of antilymphocytic antibodies. The method used was the microcytotoxicity technique employing the plastic Terasaki plates and rabbit complement.

Eighty-one of the 518 specimens tested were found to contain white cell antibodies, ie, $15 \%$. Of these 81 sera, 39 contained antibodies which could be identified, 23 being monospecific 10 dispecific, and six containing more than two antibodies. The white cell antibodies in the other 42 specimens were either too weak to identify, polyspecific, or unidentifiable specificities.

The white cell antibodies were classified according to the WHO nomenclature (HL-A) and antibodies AA, BB, and LND were also found.

In the sample studied no significant correlation between any particular white cell and red cell antibodies was found. The most common red cell antibody in the 518 specimens was anti-D $(87 \%)$. In the specimens containing white cell antibodies the frequency of this antibody was $83 \%$ which is not significantly different.

If a larger series of specimens was tested it might be possible to obtain some correlation between red cell and white cell antibodies, but using 518 specimens no correlation could be found.

Association between Pernicious Anaemia and Rheumatoid Arthritis: a Serological Study.

H. A. GHAZI (Sheffield Royal Infirmary)

We have attem pted a study of a possible association between rheumatoid arthritis and pernicious anaemia by screening 99 patients with pernicious anaemia (40 men, average age $65 \cdot 2$ years; 59 women, average age $66 \cdot 2$ years) for rheumatoid factor and 135 latex fixation seropositive patients with rheumatoid arthritis (55 men, average age 52.7 years; 80 women, average age 49.3 years) for intrinsic factor antibody. Control sera from 172 subjects $(87$ men, average age 59.7 years; 95 women, average age 53.8 years) not known to be suffering from pernicious anaemia, rheumatoid arthritis, thyroid disease, or diabetes mellitus were tested for both rheurnatoid factor and intrinsic antibody. The latter was detected by a modified charcoal adsorption technique and rheumatoid factor by latex fixation (Rheuma-Wellcotest).

Intrinsic factor antibody was not found in any of the 135 latex fixation-positive rheumatoid sera or 182 control sera, whereas $51 / 99$ pernicious anaemia sera were intrinsic factor antibody positive. Of the patients with pernicious anaemia five ha्త evidence of clinical rheumatoid arthritis and 11 (five men, six women) had rheum产 toid factor in the serum. Seven of 182 control sera were latex fixation positio (four men, three women); a comparisom with the per nicious anaemia group showed a significantly greater incidence rheumatoid factor in the latter $\left(\chi^{2} 5 \cdot 64\right.$, p 0.025-0.010). On excluding all subjects below the age of 50 from the study, the incidence of rheumatoid factor was 11 of 94 in patients with pernicious anaemfs (five men, six women) and five ơ 115 controls (two/63 men, three/s women). On comparison, again there wh a significantly higher incidence of rheb̆o matoid factor in the patients with per-y nicious anaemia $\left(\chi^{2} 3 \cdot 94, \mathrm{P} 0.05-0.02\right)$.

Within the pernicious anaemia groto the incidence of rheumatoid factor was nq significantly greater among those with intrinsic factor antibody (seven/51) that those without the antibody (four 48 ) $\left(\chi^{2} 0 \cdot 78\right.$, P $\left.0 \cdot 50-0 \cdot 30\right)$.

Fatal Pneumonia of Infancy Associated with Group O Streptococci C. A. MORRIS (Public Health Laborafory Service, Shrew'sbury)

Group O streptococci may occasional cause acute tonsillitis (Boissard arf Wormald, 1950) and have been isolate from the blood of an adult with pne monia (Duma, Weinberg, Medrek, an Kunz, 1969). Recorded here is an isolation from a 3-month-old baby. The child wa्म well the night before death, but was hean gurgling at 6.45 am and found dead $9.20 \mathrm{am}$.

At necropsy, seven hours later, th infant appeared well nourished and appropriate size for its age. Appearances suggested the child had died lying on i right side. The larynx, trachea, and bronclip contained fine froth. Both lungs were mottled by slight patchy collapse and histology showed marked oedema an patchy, but heavy, infiltration of the as sacs by mononuclear cells. Scanty cockj were seen in some sections. There was ne evidence of aspiration of vomit.

Smears from lung parenchyma showed moderate numbers of pus cells but m organisms. A moderate and pure grow种 of beta-haemolytic streptococci was cuf tured.

The bacteria showed characterist colonies and biochemical reaction 